\title{
CONTINENTAL-SLOPE SEDIMENTATION: The View From Northern CALIFornia
}

\author{
By James P. Syvitski, Clark R. Alexander, \\ Michael E. Field, James V. Gardner, \\ Daniel L. Orange and Janet W. Yun
}

\begin{abstract}
$\mathrm{T}$ HE SLOPE PORTION of the STRATAFORM program sets out to establish a better understanding of the sedimentary processes important in developing the stratigraphic record of continental slopes over the past $10^{\circ}$ years. To understand how sediment sequences and their bounding surfaces form on slopes, the project seeks to investigate processes that influence sediment erosion, transport, and accumulation. Project objectives include identification of the sources, fluxes, and mechanisms of sediment transported to and deposited on the slope: determination of the fluxes and mechanisms of sediment remobilized, eroded, and transported within and out of the slope; examination of how the processes identified above interact to form slope strata, unconformities, sequences, and morphology. In this paper we report on the approach to meeting these tasks, some preliminary field results, and future plans.
\end{abstract}

\section{Considerations for Selection of Study Area}

Morphology of many continental slopes may reflect processes active during falling or low stands of sea level, when rivers discharged directly onto the slopes. At the present ocean levels, in contrast. slopes are often disconnected from fluvial sediment sources. An appropriate study site requires active sediment deposition onto both continental shelf and slope, and a variety of mass movement features with some generated in recent times. Ideal study sites would contain open-slope and submarine-canyon morphologies, as both environments are assumed to be areas of sediment transport. One STRATAFORM study site, the

James P. Syvitski. Institute of Arctic and Alpine Research. University of Colorado. Boulder, CO 80309-()-450. USA: Clark R. Alexander. Skidaway Institute of Oceanography, 10 Ocean Science Circle, Savamnah, GA 31411. USA: Michael E. Field. Janes V. Gardner. United States Geological Survey. 345 Middlefield Road. Menlo Park, CA 94025. USA: Daniel L. Orange. Monterey Bay Aquarium Research Institute. PO Box 628, Moss Landing, CA 95039 USA: Janet W. Yun, Department of Earth Sciences \& Institute of Tectonics, University of Caltornia, Santa Cruz, CA 95064. USA. continental margin of northern California, offers a steady influx of sediment (e.g.. discharges from the Eel and Mad Rivers). where modern deposits extend onto the slope. The area is seismically active and earthquake shocks, a process considered important for initiating down-slope mass movements, are common. Gas hydrates, gas vents, and fluid seeps are also known in this area and could contribute to a decrease in sediment strength (Field and Kvenvolden. 1985). The New Jersey STRATAFORM site in contrast, offers a passive margin that receives lower sediment input at present, and downslope movements appear related to mass wasting during lower relative sea levels of the Pleistocence period.

\section{Preliminary Northern California Slope Results}

\section{Sedimentation Rates and Sediment Delivery}

In September, 1995, 39 cores were collected from 10 transects across the Eel slope (see Nittrouer and Kravitz, 1996, this issue), at 150, 250. 350 , and $450 \mathrm{~m}$ water depth. Box cores were sampled for radiochemical ( ${ }^{2+} \mathrm{Th}$ for mixing rates and 2) $\mathrm{Pb}$ for accumulation rates) and sedimentological (grain size, porosity, and sedimentary structure) analyses. The water column was studied for the sediment load that it carried. Transmissometer profiles (Fig. 1) document a bottom turbid layer (up to $150 \mathrm{~m}$ thick) that increases in thickness from south to north within the study area. One interpretation of the thicker turbid layer in the north is that it reflects sediment accumulation patterns within this area.

Eel margin slope deposits are dominated by fine-grained sediment. They show a transition from sandy silt with mean sizes of 6-7 phi (16 $\mu \mathrm{m}$ to $8 \mu \mathrm{m}$ ) in the south near the Eel Canyon, to clayey silt with mean sizes of 7-8 phi $(8 \mu \mathrm{m}$ to 4 $\mu \mathrm{m})$ in the northern portion of the study area. Sediment porosity also increases by $\sim 10 \%$ from south to north along regional isobaths. Both observations suggest material that enters the coastal ocean during river floods is transported northward
To sediment sequences and their bounding surfaces form on slopes . . . 


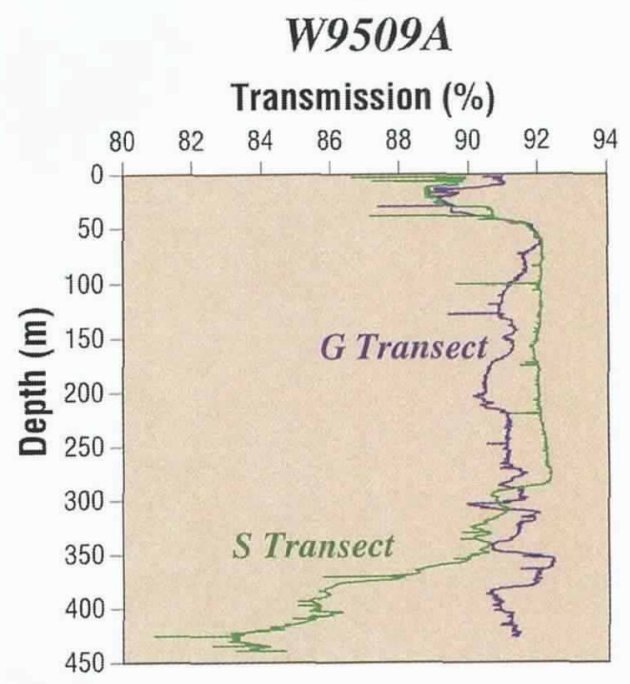

Fig. 1: Water-column transmissometer profiles during September 1995 from the southern $(G)$ and northern regions $(S)$ of the study area. Water depth is $450 \mathrm{~m}$ in both cases. Note the prominent bottom turbid layer in the north that is not observed in the south. Suspended-sediment concentrations within this layer are typically 5-10 $\mathrm{mg} \mathrm{l}^{-1}$.

\section{Accumulation rates}

on the slope... .

range from 1 to 4

$\mathrm{mm} \mathrm{y}^{-1}$.

by seasonal poleward-flowing currents (Wheatcroft et al., 1996, this issue).

We also observe a characteristic coarsening in grain size at the core stations in $250-350 \mathrm{~m}$ across the study area. There can be as much as 1 phi unit $\left(-\log _{2}\right.$ of particle diameter in $\left.\mathrm{mm}\right)$ difference in mean size between adjacent sites. This coarsening indicates preferential accumulation of finer-grained rapidly, if not directly. 'Be was detected in slope sediments collected $<1$ month after the major January 1995 flood of the river (Wheatcroft et al., 1996, this issue), but was not present in September 1995 when the stations were reoccupied.

\section{Seismic Sequences}

Characteristics of modern slope deposits evolve from a combination of sediment erosional and depositional mechanisms. Slope sequences are characterized by complex geometries and relationships and vary markedly in architecture and origin from those of the shelf system. To link these mechanisms with the character of a resultant strata (internal geometry, continuity, extent, and lateral relationships), high-resolution seismic-reflection data were collected offshore of Eureka using a Huntec seismic profiler. Our Huntec data offer a vertical seabed resolution of $25 \mathrm{~cm}$ and provide information on stratal character within the upper $50 \mathrm{~m}$ of the upper sediment column. Results will be compared eventually with sediment-core samples to link subsurface patterns with those of the seismic record for the recent sediment layers.

Slope sequences on the Eel margin are composed of downslope diverging strata and lensoidshaped beds that originate on the upper slope (300 $\mathrm{m})$. Gas is abundant throughout the area, as evi-

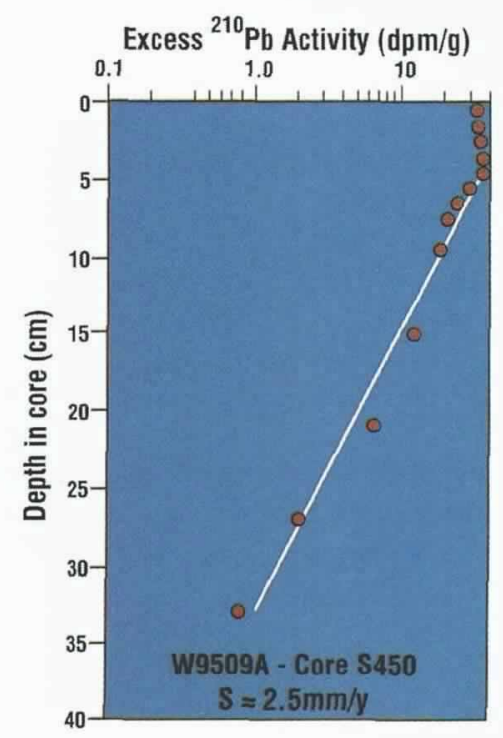
material at the upper $(150 \mathrm{~m})$ and lower $(450 \mathrm{~m})$ sites and suggests a zone of relative sediment bypassing or removal (see Austin et al., 1996, this issue). An interesting question is whether this distribution of grain sizes results from the energetic effects of internal waves interacting with the bottom.

Mottled sediments, indicating an active benthic community, dominate the sedimentary structures preserved within the upper $3 \mathrm{~m}$ of the sea floor. Bottom waters in areas shallower than $600 \mathrm{~m}$ are well-oxygenated $\left(\mathrm{O}_{2}>0.5 \mathrm{ml} \mathrm{l}^{-1}\right)$. The center of an oxygen minimum zone impinges on the slope between 600-900 m water depth. Although sedimentary structures are dominated by biological mottling, remnant depositional stratification is observed in cores throughout the region.

Accumulation rates on the slope, based on ${ }^{210} \mathrm{~Pb}$ geochronology, range from 1 to $4 \mathrm{~mm} \mathrm{y}^{-1}$ (Fig. 2). Rates are higher to the north, indicating more rapid accumulation and a larger particle flux to this region. Along-shelf flow is to the north during the winter, when most floods of the Eel River occur (Wiberg et al., 1996, this issue). ${ }^{7} \mathrm{Be}$, a tracer of flood-derived material with a 53-day halflife, shows that riverine sediment reaches the slope
Fig. 2: Representative radiochemical profile from cess ${ }^{210} \mathrm{~Pb}$ exhibit surface mixed layers $(4-8 \mathrm{~cm}$ thick) and give accumulation rates of 1-4 mm/y. Profiles of ${ }^{234}$ Th activity show radionuclide penetration to 4-8 cm within the seabed, corresponding to the mixed-layer thickness in ${ }^{210} \mathrm{~Pb}$ profiles and giving mixing coefficients of $20-60 \mathrm{~cm}^{2} y^{-1}$. ${ }^{234} \mathrm{Th}$ inventories demonstrate that particles are preferentially delivered to the northern region of the study area. the slope adjacent to the Eel River. Profiles of ex- 
denced by anomalous seismic signals from the subsurface and pockmarks (probable seep craters) on the surface. Slope sequences are locally complex due to structural compression and shear; in several places sediment packets are stacked atop one another. Throughout the slope sequences, the prevalence of slide blocks and climbing channel systems indicate that stratigraphic packages may be built largely by mass-sediment-movement processes.

The upper slope appears to be a zone of minor deposition and/or erosion under present-day conditions, i.e., a zone of bypass. Beds are eroded and crop out on the seafloor (see Austin et al., 1996, this issue). High-frequency sidescan-sonar patterns show that the zone of outcropping beds correlates with high acoustic backscatter (see Goff et al., 1996, this issue).

\section{Channels}

One apparently important feature of the slope surface and subsurface on the Eel margin is the presence of small channels crossing the slope at depths of 300-700 meters (see Goff et al., 1996, this issue). Channels are normal to the slope, relatively straight, and spaced irregularly at distances of 100 to $>500 \mathrm{~m}$. Channel size is relatively consistent: on the order of 10 to several 10's of meters wide and $<5 \mathrm{~m}$ deep (Fig. 3). Most start at or below $300 \mathrm{~m}$ and continue onto the Eel Plateau at water depths of 600-900 m.

A striking characteristic is the presence of the channels in the subsurface. Many can be traced downward from the surface for 10's of meters (Fig. 3), suggesting a strong link with sediment accumulation on the slope. If the channels represent conduits of sediment gravity flows, then these flows are a dominant mechanism of slope progradation, and our understanding of how slope sequences evolve in this area will be significantly advanced.

Slope channels have been reported from other slope settings as well (e.g., patches on the California Arguello slope: Reynolds and Gorsline, 1988; New Jersey margin: Pratson et al., 1994). These features have been variously attributed to gas-induced overpressurization along fractures, turbidity-current flow, fluidized mass wasting, and internal gravity waves. Side-scan images indicate that channels occur in areas of gas pockmarks, but their distributions are not coincident. The origin of these channels and their role in contemporary sediment redistribution on the Eureka margin are important issues to resolve.

\section{Humboldt Slide Zone}

The Humboldt Slide Zone on the southern portion of the Eureka margin is a well-known feature (Field et al., 1980; Lee et al., 1981). The upper portion of the amphitheater "scar" shows characteristics that suggest it is a zone of extensional retrograde failure. Uplift of an adjacent anticline has

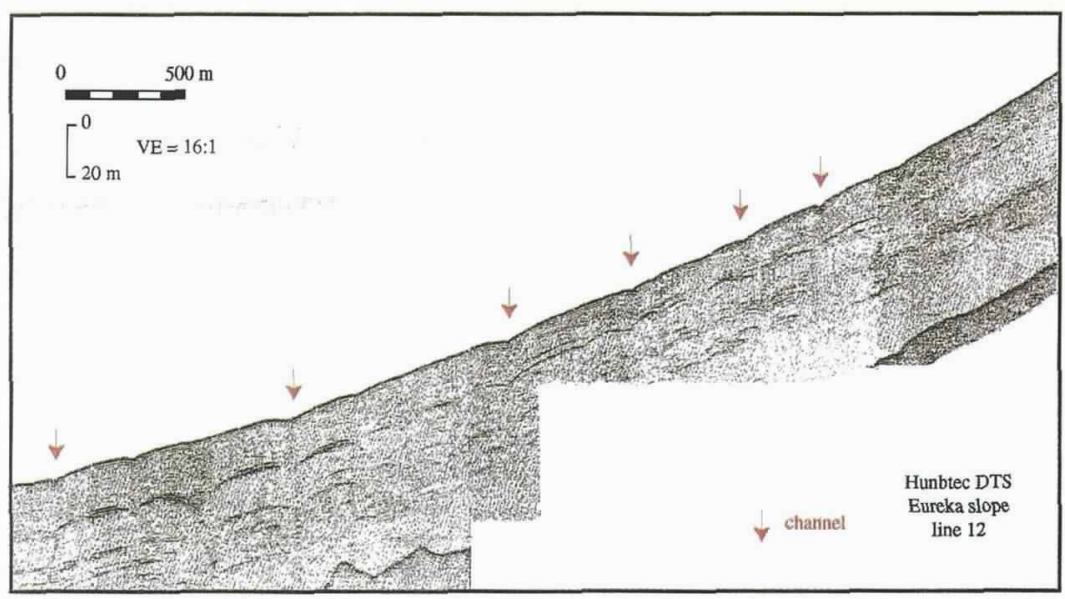

Fig. 3: Huntec Deep-Tow System (DTS) showing well-developed gully formation in both surface and subsurface for the northern part of the survey in water depths of 300-500 m.

affected a portion of the outer shelf, causing extensional failure along the slope. Successive elongate blocks, or ridges, dominate the morphology (Fig. 4). At the distal end of the Humboldt Slide Zone, acoustic reflectors are rhythmically folded, and the amplitude of the folding appears to decrease downslope. These folds may represent the zone of compressional deformation at the toe of the failure. One working hypothesis combines an upper region of retrograde extension with a lower region of compressional folding, all occurring along a distance of $\sim 3.5 \mathrm{~km}$. Disrupted reflectors $20-40 \mathrm{~m}$ below the seafloor suggest a recurrence of failure events. Another working hypothesis focuses on the origin of these features as bedforms deposited by sedimentdensity flows down the slope.

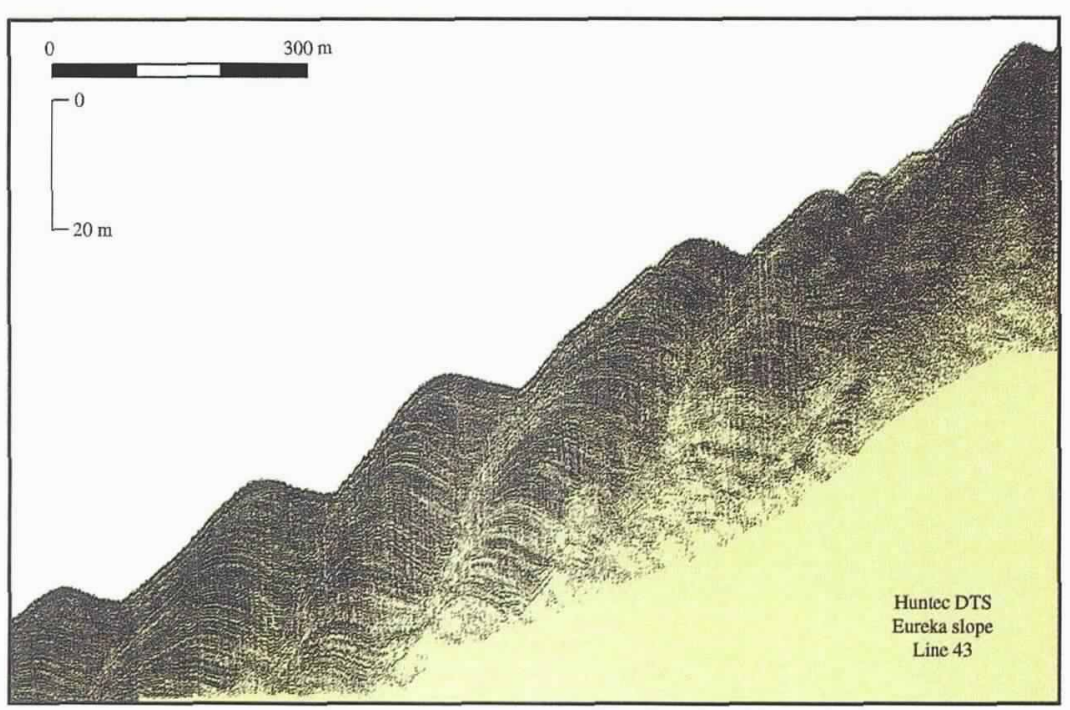

Fig. 4: Huntec DTS across the upper part of the Humboldt Slide Zone (southern region of the survey) in water depths of $\sim 400 \mathrm{~m}$, showing sediment-gravity deposits. 
Tectonics, Fluid Expulsion and Cold-Seep Communities

The Eureka margin lies just north of the Mendocino triple junction where the Pacific, North American, and Gorda/Juan de Fuca plates collide. Movements of these plates cause the region to be geologically active, with at least one seismic event larger than magnitude 6 occurring per decade (Couch et al., 1974), some of which have been linked to slope failure and mass movement (Field, 1993). In the Eel River area, the North American plate is colliding with the Gorda/Juan de Fuca plate, forcing it to subduct beneath the North American plate. During this subduction process, a thick sedimentary sequence from the subducting Gorda/Juan de Fuca plate is scraped off and accreted to the North American plate margin. The resultant sedimentary package is accreted via thrust faults, and folded into large synclines and anticlines, resulting in a wedge of sediments called an accretionary prism.

The Eel River Basin site has all the ingredients necessary for fluid overpressuring at depth: tectonic compression, sediment loading, and hydrocarbon formation. Coastal tectonic uplift and high erosion rates create conditions conducive to rapid and voluminous deposition of organic-rich sediments into the offshore Eel River Basin. A thick sedimentary sequence has accumulated in the basin, with sediment loading driving compression and fluid overpressuring. The regional distribution of gas and overpressured fluids can be inferred from multichannel seismic (MCS) data. Gas dispersed in the subsurface obstructs the passage of the acoustic wave, resulting in acoustically blank areas, or it might pool at the crest of an anticline

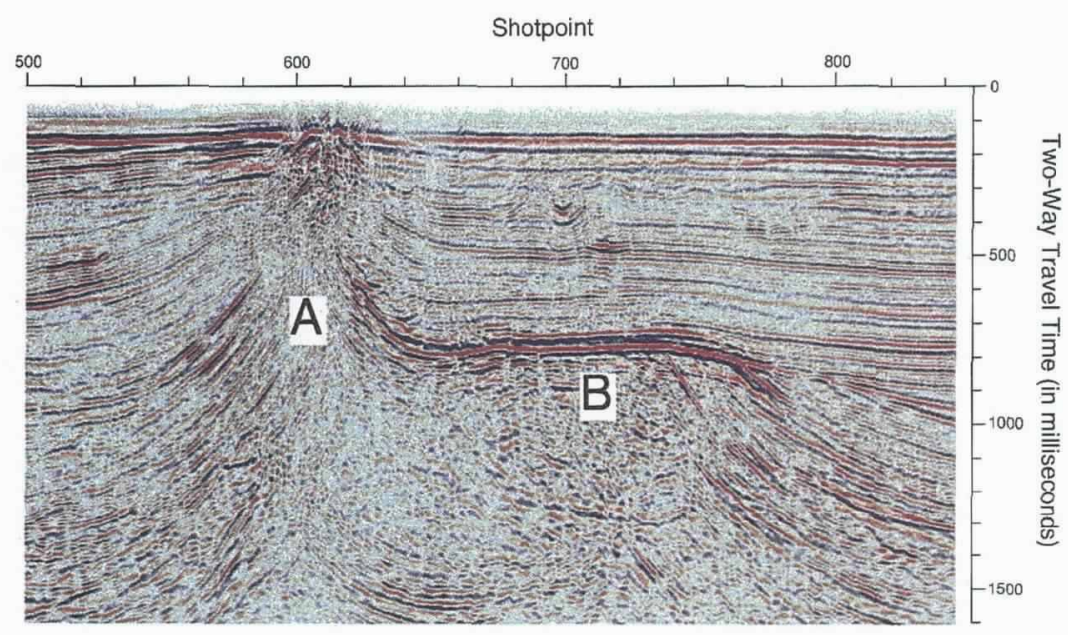

Fig. 5: Representative seismic line showing inferred mud diapir (location A) and gas trapped at the crest of the truncated anticline (location B). Every 100 shotpoints $\approx 9 \mathrm{~km}$. Travel time of the acoustic wave depends on the velocity of the sediment; 1,000 ms $\approx 1,000 \mathrm{~m}$. Data provided by Amoco Corporation and acquired by JEBCO Geophysical.
(Fig. 5), causing a strong reflection where the acoustic wave passes from sediment to gas and back. Preliminary studies show that gas abundance is regionally variable throughout the Eel River Basin, and areas containing the most gas are correlated with seafloor failure features. A bottom simulating reflector (BSR) in the seismic lines suggests the presence of clathrate (methane ice) in this area (Field and Kvevolden, 1985). Such overpressured fluids can have dramatic effects on faulting at depth, the creation of mud diapirs and mud volcanoes, and slope failure at the surface. In the Eel River Basin, our data show numerous mud diapirs and mud volcanos (Fig. 5), indicating potential locations of gas and fluid expulsion. The released fluids, rich in methane and sulfide produced during diagenesis of buried organic matter, support cold-seep communities in a food chain that is based on microbial utilization of the fluids to produce energy for biosynthesis. These unusual ecosystems of marine organisms live where overpressurized fluids exit the seafloor.

\section{Future Research Plans}

The STRATAFORM slope research group has identified a number of important research questions for the next phase of the program. Are the channels erosional on short time-scales and depositional on longer ones? Is the gas leakage from the seabed a cause or an effect of the channels? What is the role of the California Current and California Undercurrent on seabed stress of the slope? Do internal waves play a role in slope erosion? By examining the nature and timing of seafloor layering, we hope to determine the relative importance of hiatuses and erosional unconformities in the long-term development of the sediment record. Through integration of field and laboratory measurements with modeling efforts, we aim to predict key aspects of the geology for other study areas that have comparable continental shelves and slopes.

\section{Acknowledgements}

We thank Donn Gorsline, Lincoln Pratson, Chuck Nittrouer, and Joe Kravitz for their comments on an earlier draft. We also acknowledge with much appreciation our students and technical staff for their hard efforts in helping to acquire the data sets presented in this report.

\section{References}

Austin, J.A., Jr., C.S. Fulthorpe, G.S. Mountain, D.L. Orange and M.E. Field, 1996: Continental-margin seismic stratigraphy: assessing the preservation potential of heterogeneous geologic processes operating on continental shelves and slopes. Oceanography, 9, 173-177.

Couch, R.W., L.P. Victor and K.M. Keeling, 1974: Coastal and offshore earthquakes of the Pacific Northwest between $39^{\circ}$ and $49^{\circ} \mathrm{N}$ latitude and $123^{\circ}$ and $131^{\circ} \mathrm{W}$ longitude. School of Oceanography, Oregon State University Press, Corvallis, Oregon, $67 \mathrm{pp}$.

Field, M.E., 1993: Liquefaction of continental shelf sediment; 
the Northem California earthquake of 1980. In: U.S. Geological Suney Bulletin, B2002, W.C. Schwab, H.J. Lee and D.C. Twitchell, eds.. U.S. Geological Survey, Reston, Virginia, 143-150.

and Kvenvolden. K., 1985: Gas hydrates on the northern California continental margin. Geology, 13, 517-520.

S.H. Clarke and M.E. White, 1980: Geology and geologic hazards of offshore Eel River Basin, northern California continental margin. U.S. Geological Survey Open-File Report. 80-1080.80 pp.

Golf, J.A., L.A. Mayer, J. Hughes-Clarke and L.F. Pratson, 1996: Swath mapping on the continental shelf and slope: the Eel River basin, nothem California. Oceanography, 9. 178-182.

Lee. H.J. B.D. Edwards and M.E. Field, 1981: Geotechnical analysis of a submarine slump. Eureka. California. I3th Offshore Technology Conference. 53-59.

Nittrouer. C.A. and J.H. Kravitz, 1996: STRATAFORM: a program to study the creation and interpretation of sedimentary strata on continental margins. Oceanography, 9. 146-152

Pratson, L.F., W.B.R. Ryan. G.S. Mountain and D.C. Twitchell. 1994: Submarine canyon initiation by downslope eroding sediment flows; evidence in Late Cenozoic strata on the New Jersey continental slope. Geol. Sox. Am. Bull. 106. $395-412$.

Reynolds. S. and D. Gorsline. 1988: Some enigmatic depressions on the Arguello slope, California. Gee-Mar. Letts., 8, 167-172.

Wheatcroft, R.A.. J.C. Borgeld. R.S. Born, D.E. Drake, E.L. Leithold. C.A. Nittrouer and C.K. Sommerfield. 1996: The anatomy of an oceanic flood deposit. Oceamogra$p h y, 9,158-162$

Wiberg, P.L., D.A. Cacchione, R.W. Sternberg and L.D. Wright, 1996: Linking sediment transport and stratigraphy on the continental shelf. Oceanography, 9, 153-157. 